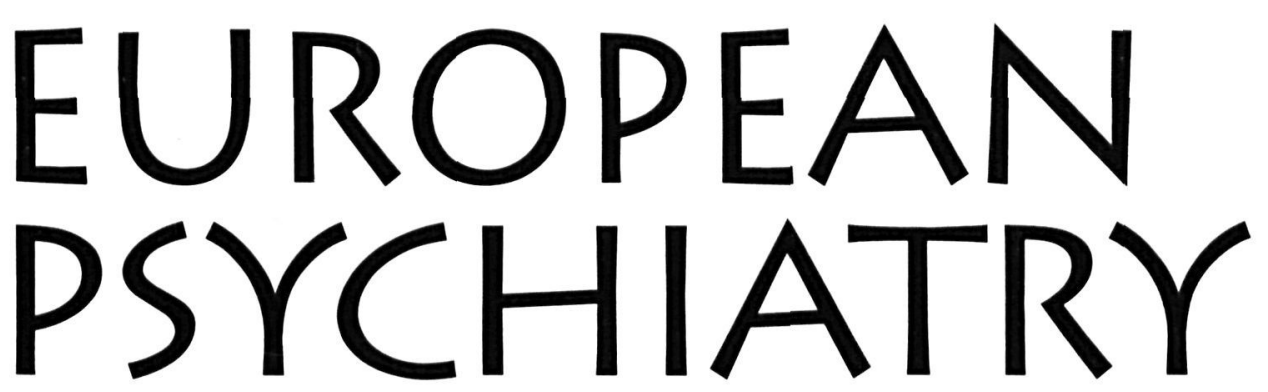

THE JOURNAL OF THE ASSOCIATION OF EUROPEAN PSYCHIATRISTS

\section{AEP NEWS}

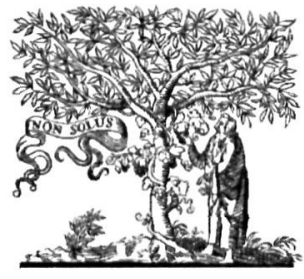

\section{AEP President's Report}

G. Sedval

\section{ORIGINAL ARTICLES}

Quality of life and standard of living in a randomly selected group of psychiatrically disabled people in Sweden 2 years after a psychiatry reform I. Carlsson et al.

Stimulus-induced craving and startle potentiation in abstinent alcoholics and controls S.M. Grüsser et al.

Multisensory integration for spatial orientation in trait anxiety subjects: absence of visual dependence I. Viaud-Delmon et al.

Are bipolar I depressive patients less responsive to treatment with antidepressants than unipolar depressive patients? Results from a case control study

R. Bottlender et al.

Clinical relevance of electroconvulsive therapy (ECT) in adolescents with severe mood disorder: evidence from a follow-up study

o. Taieb et al.

Costs and outcomes of risperidone treatment in schizophrenia in the Czech Republic

L. Hosák, R. Bahbouh

\section{SHORT COMMUNICATIONS}

Clinical profiles relating gender and depressive symptoms among adolescents ascertained by the Beck Depression Inventory II

R. Coelho et al.

5- $\mathrm{HT}_{2 \mathrm{~A}}$ gene promoter polymorphism as a moditying rather than a vulnerability factor in anorexia nervosa A. Kipman et al.

\section{CASE REPORTS}

Cyproheptadine in treatment of autism S.S. Gudarzi et al.

Elficacy of lithium treatment in Kleine-Levin syndrome

F. Muratori et al.

Coexistence of Capgras and Frégoli syndromes in a single patient. Clinical, neuroimaging and neuropsychological findings

L. Lykouras et al.

\section{LETTERS TO THE EDITOR}

Partial hospitalization and outcome of anorexia nervosa

\section{Rodriguez et al.}

\section{induced agranulocytosis}




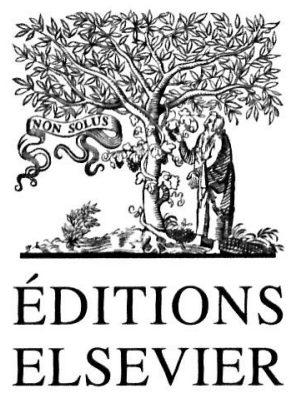

23, rue Linois

75724 Paris cedex 15, France http://www.elsevier.fr

A member of Elsevier Science

Éditions scientifiques et médicales Elsevier SAS au capital de $12198000 €-399113877$ RCS Paris
Desk editor - Brad Stucky

Tel.: (33) 0145589831 - Fax: (33) 0171724653 - E-mail: europsy@ elsevier.fr

Advertising - Elisabeth de la Fuente

Tel.: (33) 01455898 93/98 15 - Fax: (33) 0171724654 - E-mail: pub1@elsevier.fr

Subscriptions - Françoise Audiger

Tel.: (33) 0171724526 - Fax: (33) 0171724664 - E-mail: abt1 @ elsevier.fr

Consulting translator: P. Rousseau-Cunningham

2002 (Vol. 17) Annual subscription; 8 issues:

European Union : Individuals $230 €$; Institutions $450 €$.

Rest of the world: Individuals $260 €$ or US\$291; Institutions $480 €$ or US\$ 537 .

Full rates are listed on the subscription form in this issue. ${ }^{*}$ Special subscription conditions for individuals: payment must be direct from the individual and subscription delivery to the individual's address.

Address order and payment to Éditions Elsevier: payment by check or credit card (CB, EuroCard, MasterCard or Visa: indicate no. and expiration date); by transfer: CCP Paris no $30041000011904540 \mathrm{H} \mathrm{020/70.}$

Subscriptions begin 4 weeks after receipt of payment and start with the first issue of the calendar year. Back issues and volumes are available from the publisher. Claims for missing issues should be made within 6 months of publication. Includes air delivery.

No responsibility is assumed by the Publisher for any injury and/or damage to persons or property as a matter of products liability, negligence or otherwise, or from any use or operation of any methods, products, instructions or ideas contained in the material herein. Because of rapid advances in the medical sciences, independent verification of diagnoses and drug dosages should be made.

Although all advertisement material is expected to conform to ethical (medical) standards, inclusion in this publication does not constitute a guarantee or endorsement of the quality or value of such product or of the claims made of it by its manufacturer.

This journal and the individual contributions contained in it are protected by the copyright of Editions scientifiques et médicales Elsevier SAS, and the following terms and conditions apply to their use:

Photocopying - Single photocopies and single articles may be made for personal use as allowed by national copyright laws. Permission of the publisher and payment of a fee is required for all other photocopying, including multiple or systematic copying, copying for advertising or promotional purposes, resale, and all forms of document delivery. Special rates are available for educational institutions that wish to make photocopies for non-profit educational classroom use.

Users may clear permissions and make payment through the Centre Français d'Exploitation du Droit de la Copie, 20, rue des Grands Augustins, F - 75006 PARIS (France).

Derivative Works - Subscribers may reproduce tables of contents or prepare lists of articles including abstracts for internal circulation within their institutions. Permission of the publisher is required for resale or distribution outside of the institution.

Permission of the publisher is required for all other derivative works, including compilations or translations.

Electronic Storage - Permission of the publisher is required to store electronically any material contained in this journal, including any article or part of an article. Contact the publisher at the address indicated.

Except as outlined above, no part of this publication may be reproduced, stored in a retrieval system or transmitted in any form or by any means, electronic, mechanical, photocopying, recording or otherwise, without prior written permission of the publisher.

(C) 2002 Éditions scientifiques et médicales Elsevier SAS. All rights reserved

Président-directeur général et directeur de la publication - Dominique Choppin

Printed in France by Jouve, 1, rue du Dr-Sauvé, 53101 Mayenne

Dépôt légal à parution 